\title{
A Species-Specific PCR Assay for Detection of Diplodia pinea and D. scrobiculata in Dead Red and Jack Pines with Collar Rot Symptoms
}

\author{
Denise R. Smith and Glen R. Stanosz, Department of Plant Pathology, University of Wisconsin-Madison, Madison \\ 53706
}

\begin{abstract}
Smith, D. R., and Stanosz, G. R. 2006. A species-specific PCR assay for detection of Diplodia pinea and D. scrobiculata in dead red and jack pines with collar rot symptoms. Plant Dis. 90:307-313.

A polymerase chain reaction (PCR)-based assay was developed for the specific detection of the fungal pathogens Diplodia pinea and D. scrobiculata from pine host tissues. Variation among mitochondrial small subunit ribosome gene (mt SSU rDNA) sequences of Botryosphaeria species and related anamorphic fungi was exploited to design primer pairs. Forward primer DpF and forward primer DsF, each when used with the nonspecific reverse primer BotR, amplified DNA of $D$. pinea or $D$. scrobiculata, respectively. Specificity was confirmed using multiple isolates of each of these two species and those of closely related fungi including Botryosphaeria obtusa. The detection limits for DNA of each pathogen in red and jack pine bark were 50 to $100 \mathrm{pg} \mathrm{\mu l}^{-1}$ and $1 \mathrm{pg}^{-1} \mathrm{l}^{-1}$ in red and jack pine wood. The assay was tested using naturally occurring red and jack pine seedlings and saplings exhibiting symptoms of Diplodia collar rot. Samples from lower stems/root collars of 10 dead trees of each species from each of three sites at each of two locations were tested. Results were positive for D. pinea or D. scrobiculata for the large majorities of symptomatic bark and wood samples from both locations. For positive samples, however, there were effects of location and host species on detection of $D$. pinea (more frequent on red pine) and $D$. scrobiculata (more frequent on jack pine) $(P<0.01$ in both cases). These results indicate that these new primers are potentially useful for studies in areas or hosts in which both pathogens may be present.
\end{abstract}

Additional keywords: Pinus banksiana, P. resinosa, Sphaeropsis sapinea

The variation exhibited by fungi comprising the conifer shoot blight and canker pathogen complex Sphaeropsis sapinea sensu lato has prompted studies that have clarified their identity. Palmer et al. (20) recognized two forms: isolates of the A group were described as producing abundant white to gray-green aerial mycelium in culture, compared with dark gray and more appressed mycelium of B group isolates. These $\mathrm{A}$ and $\mathrm{B}$ groups were suggested to differ in radial growth rate, conidial size, texture of conidial walls, production of spermatia or microconidia, and the ability to penetrate nonwounded hosts $(20,37,38)$, but each of these characters has been shown to either vary substantially within groups or to be similar for isolates of different groups $(5,34,35,39)$. However, analyses using a variety of molecular techniques, including isozymes, RAPD and ISSR markers, and sequences of the nuclear rDNA ITS and 5.8s rDNA, microsatellite loci, and protein coding

Corresponding author: Denise Smith

E-mail: dzs@plantpath.wisc.edu

Accepted for publication 7 October 2005.

DOI: 10.1094/PD-90-0307

(C) 2006 The American Phytopathological Society genes $(9,33,40,42)$, allow clear differentiation of the two groups. Thus, the $\mathrm{B}$ group has been recognized as a distinct species and assigned the name Diplodia scrobiculata (9). Insufficient justification for the separation of Sphaeropsis from Diplodia led to the recent suggestion of reversion to the name $D$. pinea for the A group (9).

Both D. pinea and D. scrobiculata are pathogens of native and introduced pines grown in the north central United States as ornamentals or for production of Christmas trees, pulp, poles, and lumber. Inoculation of intact shoot tips of red pine (Pinus resinosa) and jack pine (P. banksiana) seedlings with conidia of either $D$. pinea or D. scrobiculata resulted in similar symptoms (5). However, in that experiment, and in subsequent studies using seedlings of pines and conifers in several other genera that were wounded and inoculated with mycelium on agar plugs, $D$. pinea isolates generally caused greater incidence and/or severity of symptoms than did isolates of $D$. scrobiculata (1,3$6,27,30)$. D. pinea also has been frequently isolated from stems of asymptomatic red pine nursery seedlings in Wisconsin and Minnesota $(25,28,31)$ and shown to proliferate to cause collar rot and rapid mortality of trees under water stress (25). Virulent isolates of $D$. pinea also have been obtained from asymptomatic tissues of Aus- trian pine ( $P$. nigra) in Kentucky (11). Most recently, isolates of $D$. scrobiculata also were obtained from asymptomatic red pine nursery seedlings, but the ability of these isolates to induce symptoms was not tested (28).

In addition to the locations and tree species mentioned above, the reported geographic and host ranges of $D$. pinea and $D$. scrobiculata are broad and overlapping. $D$. pinea is known to be widely distributed in the natural ranges of pines in the Northern Hemisphere and where these trees have been introduced in the Southern Hemisphere. Well-characterized isolates (i.e., by means of analysis of molecular markers) of D. pinea have been obtained from Africa, Asia, Australasia, Europe, and from both eastern and western North America (including Mexico). These isolates have been obtained from many species of pine, as well as species of cedar (Cedrus), larch (Larix), spruce (Picea), and Douglas-fir (Pseudotsuga) $(7,9,13,20,23,29,33)$. The geographic area in which $D$. scrobiculata is known to occur is more limited. However, well-characterized isolates have been collected in the United States from California, Florida or Georgia, Michigan, Minnesota, Wisconsin, Kentucky, and West Virginia, and also from Canada, France, Israel, Italy, and Mexico. These isolates have been obtained from at least 10 pine species, cedar, and spruce $(7,9,13,33)$.

Not only do geographic distributions and host ranges overlap, D. pinea and $D$. scrobiculata also are known to occur together. For example, both species have been obtained from individual red pine plantations in Minnesota (18) and from red pine seedlings in a Minnesota nursery (28). Other reports include detection of these two species from a single tree. The isolates of Morelet and Chandelier (17) that corresponded to $D$. pinea and D. scrobiculata (33) were each obtained from a single deodar cedar (Cedrus deodara) tree in France. Finally, attempts by Palmer et al. (20) to reisolate from plantation red pines previously inoculated with $D$. pinea also sometimes yielded $D$. scrobiculata.

Overlapping host and geographic ranges and similarities in symptoms and morphology can make identification of $D$. pinea and D. scrobiculata difficult and complicate studies of disease etiology. Investigation of these pathogens and diseases they cause would be facilitated by methods to rapidly detect each species, 
especially directly from host tissues collected from the field. A two-step polymerase chain reaction (PCR) assay using primers based on nuclear rDNA ITS sequence was developed by Flowers et al. (10) to identify $D$. pinea in Austrian pine tissues. Due to high similarities in ITS sequences (42), that assay cannot differentiate among $D$. pinea, $D$. scrobiculata, and a third pathogen that also can be associated with conifers, Botryosphaeria obtusa $(9,13,21)$. A previous phylogenetic analysis of the mitochondrial small subunit ribosome gene (mt SSU rDNA) revealed a region of substantial sequence variation among Botryosphaeria species and related anamorphic fungi, including Diplodia species (41). Our objectives were to further explore sequence variation in this region, and to exploit this variation to develop specific primers for detection of $D$. pinea and D. scrobiculata. The widespread occurrence of dead red and jack pine seedlings with collar rot symptoms in central Wisconsin in 2004 offered the potential to test DNA extraction procedures and $\mathrm{mt}$
SSU rDNA primers using diseased host tissues, and to further investigate the association of these pathogens with their hosts.

\section{MATERIALS AND METHODS}

Fungal isolates. Fungal isolates used in designing and testing mt SSU rDNA primers were acquired by the authors or cooperators from host plants or were purchased from collections (Table 1).

DNA sequencing and primer design. Procedures, materials, and equipment for genomic DNA extraction from fungal cultures were similar to those previously described (23). All DNA extractions and PCR analyses were carried out using standard procedures to avoid cross-contamination of DNA. Negative controls (no DNA) were always included. Most mt SSU rDNA sequences were acquired in a previous study (41). Other sequences were obtained by amplifying the variable region of the $\mathrm{mt}$ SSU rDNA using primers MSU1 and BotR (Botryosphaeria-specific primer derived from Zhou and Stanosz [41] sequences; Table 2) or MSU1 and NMS2 (15). DNA was amplified in a 50- $\mu \mathrm{l}$ reaction with 0.8 $\mu \mathrm{M}$ each primer (University of WisconsinMadison Biotechnology Center), $600 \mu \mathrm{M}$ dNTPs, $1 \times$ buffer, $2.0 \mathrm{mM} \mathrm{MgCl} 2,1 \mathrm{U}$ Taq DNA polymerase (all purchased from Promega Corp., Madison, WI), and 2 to 10 ng of fungal DNA. The following temperature profile was used in a Biometra $\mathrm{T} 1$ Thermocycler (Whatman Biometra, Goettingen, Germany): 1 cycle of $5 \mathrm{~min}$ at $95^{\circ} \mathrm{C}$ followed by 30 cycles of $1 \mathrm{~min}$ at $95^{\circ} \mathrm{C}, 1 \mathrm{~min}$ at $53^{\circ} \mathrm{C}, 1 \mathrm{~min}$ at $72^{\circ} \mathrm{C}$, followed by 1 cycle of $5 \mathrm{~min}$ at $72^{\circ} \mathrm{C}$. Fragment sizes were verified on $0.7 \%$ agarose gels in Tris-boric acid-EDTA buffer (TBE). The fragments were purified using the QIAGEN QIAquick PCR Purification Kit (QIAGEN Inc., Chatsworth, CA), labeled with the BigDye Terminator Cycle Sequencing Kit (Applied Biosystems, Foster City, CA), then analyzed by the University of Wisconsin Biotechnology Center on an Applied Biosystems 3730XL DNA sequencer. The sequenced regions of the $\mathrm{mt}$ SSU rDNA were aligned using ClustalX $1.64 \mathrm{~b}$ (36) with gap penalty $=25$ and gap

Table 1. Isolates used in designing and testing mt SSU rDNA primers for species-specific polymerase chain reaction (PCR) assay to detect Diplodia pinea and D. scrobiculata

\begin{tabular}{|c|c|c|c|c|c|c|}
\hline Species & Isolate no. & Host & Location & Collector & $\begin{array}{l}\text { SSU GenBank } \\
\text { accession no. }\end{array}$ & $\begin{array}{l}\text { Other } \\
\text { collection no. }\end{array}$ \\
\hline \multirow[t]{8}{*}{ Diplodia pinea } & 411 & Pinus resinosa & Minnesota & M. Palmer & AF051636 & DAOM 229440 \\
\hline & $92-19$ & P. resinosa & Wisconsin & G. R. Stanosz & & \\
\hline & $92-50$ & $P$. radiata & South Africa & W. Swart & AF051636 & ATCC 64714 \\
\hline & $93-23$ & P. radiata & Australia & E. Davison & & \\
\hline & $94-19$ & Cedrus deodara & France & P. Chandelier & & \\
\hline & 94-139 & P. sylvestris & Netherlands & B. van Dam & & \\
\hline & $96-40$ & P. halepensis & Israel & Z. Solel & & \\
\hline & $98-6$ & P. elliottii & China & G. Peterson & & \\
\hline \multirow[t]{8}{*}{ D. scrobiculata } & 113 & P. banksiana & Michigan & M. Palmer & AF051637 & DAOM 229441 \\
\hline & 124 & P. banksiana & Wisconsin & M. Palmer & & DAOM 222531 \\
\hline & 474 & P. resinosa & Minnesota & M. Palmer & & \\
\hline & $94-17$ & C. deodara & France & P. Chandelier & & \\
\hline & $96-39$ & P. halepensis & Israel & Z. Solel & & \\
\hline & $96-46$ & P. elliottii & Florida or Georgia & S. Fraedrich & & \\
\hline & $97-73$ & Pinus sp. & Italy & L. Sparapano & & \\
\hline & $98-1$ & P. taeda & Georgia & C. Rodriguez & & \\
\hline D. pinea f. sp. cupressi & $94-158$ & Cupressus sempervirens & Israel & Z. Solel & AF271131 & DAOM 229439 \\
\hline \multirow[t]{2}{*}{ Botryosphaeria rhodina } & $96-3$ & Quercus sp. & California & E. Hecht-Poinar & AF051641 & ATCC 208824 \\
\hline & $96-172$ & Theobroma cacao & Sri Lanka & E. Müller & AF271142 & CBS 356.59 \\
\hline \multirow[t]{2}{*}{ D. mutila } & $94-6$ & Malus sp. & New Zealand & N. Tisserat & & \\
\hline & $97-85$ & Malus pumila & Unknown & H. Boeswinkel & AF271140 & ATCC 60259 \\
\hline \multirow[t]{3}{*}{ B. obtusa } & $95-81$ & Prunus armeniaca & Wisconsin & E. Smalley & & \\
\hline & $96-2$ & Cercis canadensis & Washington, D.C. & G. Samuels & DQ023299 & ATCC 208826 \\
\hline & $96-115$ & Prunus persica & Georgia & K. Britton & DQ023298 & ATCC 60851 \\
\hline B. quercuum & $96-186$ & Q. cerris & Italy & A. Vannini & AF271141 & CBS 177.89 \\
\hline B. tsugae & $96-174$ & Tsuga heterophylla & Canada & A. Funk & AF271137 & CBS 418.64 \\
\hline B. dothidea & $96-6$ & Prunus persica & Georgia & P. L. Pusey & & \\
\hline \multirow[t]{2}{*}{ B. ribis } & $96-8$ & Rhizophora mangle & Florida & M. Rayacchetrey & DQ023300 & ATCC 208827 \\
\hline & $96-9$ & C. canadensis & Washington, D.C. & K. Jacobs & & ATCC 208822 \\
\hline Fusarium tricinctum & $96-145$ & Pinus banksiana & Wisconsin & D. R. Smith & & \\
\hline Cladosporium sp. & $96-146$ & P. banksiana & Wisconsin & D. R. Smith & & \\
\hline Chaetomium sp. & $96-147$ & P. resinosa & Wisconsin & D. R. Smith & & \\
\hline Schlerophoma pithyophila & $96-154$ & P. banksiana & Wisconsin & D. R. Smith & & \\
\hline Epicoccum $\mathrm{sp}$. & $96-155$ & P. banksiana & Wisconsin & D. R. Smith & & \\
\hline Alternaria sp. & $97-3$ & P. banksiana & Wisconsin & D. R. Smith & & \\
\hline \multirow[t]{2}{*}{ Pestalotiopsis sp. } & $00-2$ & P. resinosa & Wisconsin & J. Blodgett & & \\
\hline & 03-01 & P. resinosa & Wisconsin & D. R. Smith & & \\
\hline \multirow[t]{2}{*}{ Trichoderma sp. } & $00-1$ & P. resinosa & Wisconsin & J. Blodgett & & \\
\hline & 03-02 & $P$. resinosa & Wisconsin & D. R. Smith & & \\
\hline \multirow[t]{2}{*}{ Sirococcus conigenus } & $00-47$ & P. resinosa & Wisconsin & J. Blodgett & & \\
\hline & $01-04$ & Picea abies & Germany & A. Wulf & & \\
\hline Pseudorobillarda sp. & $03-05$ & Pinus resinosa & Michigan & D. R. Smith & & \\
\hline
\end{tabular}


extension penalty $=5$. Potential primer sequences were chosen manually and checked for primer-dimer, hairpins, and other sequences that would interfere with PCR using NetPrimer (online).

Primer specificity testing. Initially, seven D. pinea $(92-19,92-50,93-23,94-$ 19, 94-139, 96-40, and 98-6) and seven $D$. scrobiculata isolates $(124,474,94-17,96-$ 39, 96-46, 97-73, and 98-1) from diverse hosts and geographic locations were used to test the specificity of the primers (Table 1). DNA was extracted from liquid cultures (23) and amplified as described above.

Specificity of the primers also was tested with isolates of close relatives of $D$. pinea and $D$. scrobiculata. These species included $B$. dothidea, $B$. obtusa, $B$. quercuum, B. rhodina, B. ribis, B. tsugae, $D$. mutila, and a fungus referred to as $D$. pinea f. sp. cupressi (previously shown to be distinct from $D$. pinea) $(24,32,40)$ (Table 1). We also tested the primers using a number of other fungi we frequently have cultured from pine tissue including Fusarium tricinctum, Cladosporium sp., Chaetomium sp., Schlerophoma pythiophylla, Epicoccum sp., Alternaria sp., Pestalotiopsis sp., Trichoderma sp., Sirococcus conigenus, and Pseudorobillarda sp. (Table 1). Amplification of the DNA from all of these fungi was also attempted with the universal mt SSU rDNA primers MSU1 and NMS2 to verify that this region could be amplified even though the specific primers failed to produce amplification products.

Finally, to verify that the primers did not amplify any DNA from the host tissue, amplification was attempted on DNA extracted from bark, wood, and needles from red pine and jack pine trees that had been kept in the greenhouse and were symptomfree for 3 years. DNA was extracted from the pine tissue using the procedure of Cubero et al. (8) with slight modification. A small piece of bark (4 to $16 \mathrm{~mm}^{2}$ ) or needle $(\sim 1 \mathrm{~cm}$ long) was placed in a $1.5-\mathrm{ml}$ microcentrifuge tube with $\sim 2 \mathrm{~mm}^{3}$ of acidwashed sand $(0.25 \mathrm{~mm}$ industrial quartz, Unimin Corp., Portage, WI) and $250 \mu \mathrm{l}$ of extraction buffer ( $1 \% \mathrm{wt} / \mathrm{vol}$ hexadecyltrimethylammonium bromide [CTAB], 1
$\mathrm{M} \mathrm{NaCl}, 100 \mathrm{mM}$ Tris, $\mathrm{pH} \mathrm{8,} 20 \mathrm{mM}$ EDTA, $1 \%$ polyvinylpyrrolidone [PVP]). The plant material was ground with a sterile Kontes polypropylene pestle (Kimble/Kontes, Vineland, NJ), then incubated for $30 \mathrm{~min}$ at $70^{\circ} \mathrm{C}$. One volume chloroform:isoamyl alcohol (24:1) was added, mixed, then centrifuged for $5 \mathrm{~min}$ at $10,000 \mathrm{rpm}$. The aqueous phase was transferred to a new tube. Two volumes of precipitation buffer were added (1\% CTAB, $50 \mathrm{mM}$ Tris, $\mathrm{pH} \mathrm{8,} 10 \mathrm{mM}$ EDTA, $40 \mathrm{mM} \mathrm{NaCl}$ ), mixed by inversion for 2 min, then centrifuged at $13,000 \mathrm{rpm}$ for 5 min. The supernatant was discarded and the pellet resuspended in $350 \mu \mathrm{l}$ of $1.2 \mathrm{M}$ $\mathrm{NaCl}$. One volume chloroform:isoamyl alcohol (24:1) was added, mixed, then centrifuged for $5 \mathrm{~min}$ at $10,000 \mathrm{rpm}$. The aqueous phase was transferred to a new tube, and 0.6 volume of ice-cold isopropanol was added, mixed, and incubated at $-20^{\circ} \mathrm{C}$ for $15 \mathrm{~min}$. The samples were then centrifuged at $13,000 \mathrm{rpm}$ for $20 \mathrm{~min}$. The supernatant was removed, and $500 \mu \mathrm{l}$ of $70 \%$ ethanol was added and centrifuged at 10,000 rpm for $5 \mathrm{~min}$. The ethanol was removed and the nucleic acid pellet dried and resuspended in $50 \mu$ of sterile water.

DNA extraction procedures. Three DNA extraction procedures were tested on red pine needles and red pine bark bearing $D$. pinea pycnidia and conidia. The first was a relatively simple extraction using polyethylene glycol and sodium chloride to precipitate the DNA (14). The second procedure (8) was the one detailed above. A third procedure commonly used on plant material was also tested (10). Briefly, the plant material was ground in a CTAB buffer with sand (1\% CTAB, $0.7 \mathrm{M} \mathrm{NaCl}$, $0.1 \mathrm{M}$ Tris, $\mathrm{pH}$ 8.0, $10 \mathrm{mM}$ EDTA), incubated $1 \mathrm{~h}$ at $60^{\circ} \mathrm{C}$, proteins were removed with chloroform:isoamyl alcohol (24:1), and DNA precipitated by ice-cold isopropanol. This procedure differed from the second procedure in the absence of PVP in the extraction buffer and the absence of an extra precipitation step followed by chloroform extraction of the resuspended pellet. For all three procedures, the extracted DNA was amplified using the species- specific primers, and presence of fragments was verified on $0.7 \%$ agarose gels in TBE buffer.

Detection limit. DNA was extracted from mycelial cultures of $D$. pinea and $D$. scrobiculata (23) and quantified using a TKO 100 Mini Fluorometer (Hoefer Scientific Instruments, San Francisco, CA) and DNA-specific dye Hoechst 33258 (SigmaAldrich, St. Louis, MO). For each pathogen, six DNA dilution series were made: (i) red pine needle DNA extract as the diluent; (ii) red pine bark DNA extract as the diluent; (iii) red pine wood DNA extract as the diluent; (iv) jack pine needle DNA extract as the diluent; (v) jack pine bark DNA extract as the diluent; and (vi) jack pine wood DNA extract as the diluent. Plant DNA was extracted using the slightly modified method of Cubero et al. (8) described above. A dilution series with water as the diluent also was made for DNA of each fungus. The highest concentration of DNA tested was $10 \mathrm{ng} / \mu \mathrm{l}$ and the lowest was $1 \mathrm{pg} / \mu \mathrm{l}$. PCR reactions were performed as described above.

Tree sampling and testing. Trees were sampled during the summer of 2004 at three sites in each of two locations, one in Adams County $\left(44^{\circ} 10^{\prime} \mathrm{N}, 90^{\circ} 41^{\prime} \mathrm{W}\right)$ and the other in the Black River State Forest (BRSF) in Jackson County $\left(44^{\circ} 22^{\prime} \mathrm{N}\right.$, $\left.89^{\circ} 53^{\prime} \mathrm{W}\right)$, both in central Wisconsin. The soil type in each location is deep, welldrained to excessively well-drained sand, and the average annual precipitation is approximately $750 \mathrm{~mm}$. Prior to European settlement, barrens of jack pine and prairie grasses would have commonly occupied such locations. Red and jack pine seedlings and saplings (usually $<1 \mathrm{~m}$ tall) present at all six sites had developed naturally from seed. Recently killed seedlings and saplings of each species with symptoms of collar rot including blue to black discoloration of the inner bark and wood were common at each site.

Ten plots were located at intervals of at least $10 \mathrm{~m}$ along a transect across each site. Usually four seedlings and saplings were sampled at each plot; these were selected to be located as close together as possible, and included one recently killed

Table 2. Primer sequences with alignment to mt SSU rDNA sequences from Diplodia pinea, D. scrobiculata, and several related species

\begin{tabular}{|c|c|c|}
\hline Identities & $\begin{array}{l}\text { Species-specific forward primer }{ }^{\mathrm{a}} \\
\qquad 5^{\prime}-\mathrm{y}^{\prime}-\mathbf{3}^{\prime}\end{array}$ & $\begin{array}{l}\text { Botryosphaeria-specific reverse primer } \\
\qquad 5^{\prime}--->3^{\prime}\end{array}$ \\
\hline Primer BotR & & GCTTACACTTTCATTTATAGACC \\
\hline Primer DpF & СТTATATATCAААСТАTGCTTTG-TA & \\
\hline Diplodia pinea & СТTATATATCAААСТАTGCTTTG-TA & GCTTACACTTTCATTTATAGACC \\
\hline Primer DsF & СТTATATATCAAACTAATGTTTG-CA & \\
\hline D. scrobiculata & СТTATATATCAAАСТААТGTTTG-CA & GCTTACACTTTCATTTATAGACC \\
\hline Botryosphaeria obtusa (96-2 and 96-115) & СТTATAAATCAATCTAAGCTTTG-TA & GCTTACACTTTCATTTATAGACC \\
\hline D. pinea f. sp. cupressi (94-158) & CTTATA- - TCATACTATGATTTGGTA & GCTTACACTTTCATTTATAGATC \\
\hline B. rhodina $(96-3 \text { and } 96-172)^{\mathrm{b}}$ & СTTATATTATACAAAAAAATTGG-TA & GCTTACACTTTCATTTATAGACC \\
\hline B. ribis $(96-8)$ & СТTATATAАTACAAAAAATATC-TA & GCTTACACTTTCATTTATAGACC \\
\hline
\end{tabular}

${ }^{a}$ Bold type indicates nucleotides that differ across species.

${ }^{\mathrm{b}}$ Because B. rhodina has a large insertion in this region, this sequence occurs further downstream and the fragment generated using these primers is much larger than for the other species. 
red pine, one recently killed jack pine, one live red pine without symptoms, and one live jack pine without symptoms. Due to the absence of a live red or jack pine seedling or sapling in proximity to the other sampled trees in some plots, fewer than 10 live trees of each species were collected from some sites. A segment of the lower stem and/or root collar exhibiting symptoms of collar rot was cut from each sampled tree with surface-disinfested tools and individually bagged. These segments were placed on ice until returning to the laboratory, where they were stored at $-20^{\circ} \mathrm{C}$ until DNA extraction.

From each segment, a 4-5 × 4-5 mm sample of bark (tissues from the vascular cambium outward) was removed with a sterile scalpel and placed in a sterile $1.5-\mathrm{ml}$ microcentrifuge tube. A similarly sized sample of underlying wood was removed with a sterile scalpel and placed in a separate sterile $1.5-\mathrm{ml}$ microcentrifuge tube. Samples from dead trees were taken from an area with discolored wood. Samples were ground, DNA was extracted using the modified Cubero procedure (8), and PCR reactions were performed as described above. All samples were tested for the presence of both $D$. pinea and D. scrobiculata using the respective specific primers. At least one negative control (water) and one positive control (DNA extracted from a D. pinea or D. scrobiculata culture) was included with each PCR reaction. Fragment sizes were verified on $0.7 \%$ agarose gels in TBE buffer.

The mean frequencies of trees positive with either pathogen, and for these positive trees the mean frequencies with $D$. pinea and with $D$. scrobiculata, were calculated for dead trees of each host at each location (Table 3). Analyses of variance were used to test for effects of location, host species, and interactions on these frequencies. Percentage data were converted to proportions, and the arcsine of the square root transformation was applied before analyses were performed using Minitab for Windows version 14 (Minitab Inc., State College, PA).

\section{RESULTS}

DNA sequencing, primer design, and specificity testing. The 19-bp region of diversity among mt SSU rDNA sequences (41) allowed design of primers pairs specific for D. pinea and D. scrobiculata. We designed a $D$. pinea-specific forward primer (DpF; Table 2), a forward primer that would amplify D. scrobiculata (DsF; Table 2), and a reverse primer (BotR; Table 2) that would amplify most Botryosphaeria species and some other fungi. The primer pair DpF/BotR amplified a 700-bp fragment from $D$. pinea, but did not yield any fragments from $D$. scrobiculata or any other fungal species tested. The primer pair DsF/BotR amplified a 700-bp fragment from $D$. scrobiculata, but did not yield any fragments from $D$. pinea or any other fungal species tested. Neither primer pair yielded amplification products from red or jack pine tissues.

DNA extraction procedures. Fragments of the correct size were most likely to be amplified from DNA extracted using the procedure of Cubero et al. (8) $(90 \%$ positive for infected red pine bark; $100 \%$ for infected needles). The simpler CTAB extraction yielded $80 \%$ positive for infected bark, while the PEG precipitation yielded 50\% positive from infected red pine needles and $0 \%$ positive for infected bark.
Detection limit. The detection limit for $D$. pinea DNA diluted in red and jack pine needle or bark extract using primers $\mathrm{DpF} / \mathrm{BotR}$ was $100 \mathrm{pg} / \mu \mathrm{l}$. For $D$. pinea DNA diluted in red or jack pine wood extract, the detection limit was $1 \mathrm{pg} / \mu \mathrm{l}$. The detection limit for $D$. scrobiculata using primers DsF/BotR varied: it was 50 $\mathrm{pg} / \mu \mathrm{l}$ when diluted in red and jack pine bark and red pine needle extracts; 100 $\mathrm{pg} / \mu \mathrm{l}$ for jack pine needles extracts; and 1 $\mathrm{pg} / \mu \mathrm{l}$ for red and jack pine wood extracts. For DNA of $D$. pinea diluted in water, the detection limit with DpF/BotR was 1 $\mathrm{pg} / \mu \mathrm{l}$. For DNA of $D$. scrobiculata diluted in water, the detection limit with DsF/BotR was $1 \mathrm{pg} / \mu \mathrm{l}$.

Tree sampling and testing. Both pathogens were detected from samples collected at each of the six sites. Test results were positive for either $D$. pinea or D. scrobiculata for large majorities of bark and wood samples from dead red pine and dead jack pines from both locations (Table 3 ; example of gel in Figure 1). For example, $90 \%$ of red pine bark samples from Adams Co. tested positive and $93 \%$ of jack pine wood samples from Adams Co. tested positive. Analysis of variance of transformed data did not indicate effects of location, pine species, tissue (bark or wood), or interactions on the percentages

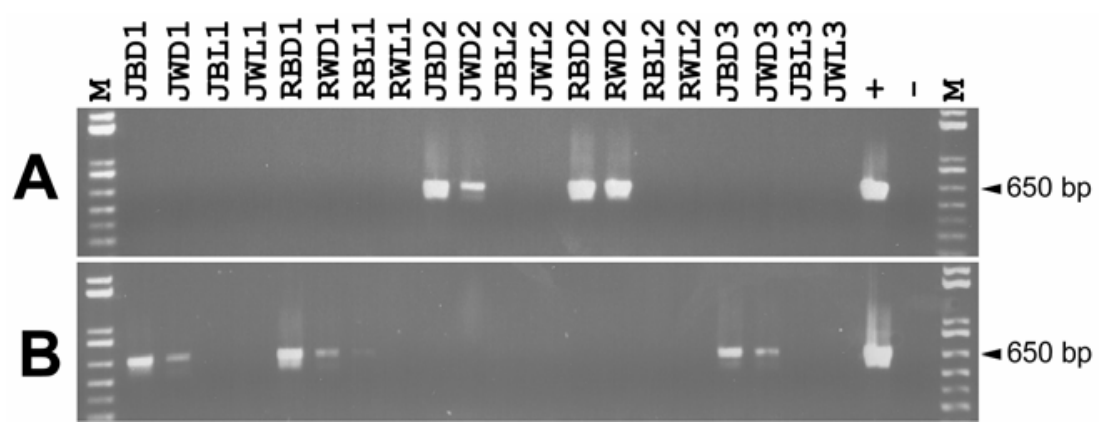

Fig. 1. Polymerase chain reaction products from DNA extracted from red and jack pine tissues. A, Products using primers DpF and BotR to detect Diplodia pinea. B, Products using primers DsF and BotR to detect D. scrobiculata. For both $\mathbf{A}$ and B: M, 1 kb Plus DNA Ladder (Invitrogen, Carlsbad, CA); J, jack pine; R, red pine; B, bark; W, wood; D, dead; L, live (no symptoms); number, plot from which seedling was collected; + , positive control DNA (D. pinea isolate 411 for A; D. scrobiculata isolate 124 for B); -, negative control (no DNA).

Table 3. Frequencies of detection of Diplodia pinea (Dp) and D. scrobiculata (Ds) in dead red and jack pines ${ }^{\text {a }}$ with collar rot symptoms that were tested using speciesspecific polymerase chain reaction (PCR) assay

\begin{tabular}{|c|c|c|c|c|c|c|c|c|c|c|c|c|c|c|c|c|c|c|c|}
\hline \multirow[b]{3}{*}{ Location } & \multirow{3}{*}{$\begin{array}{c}\text { Pine } \\
\text { species }\end{array}$} & \multicolumn{6}{|c|}{ Trees positive with either pathogen } & \multicolumn{6}{|c|}{ Positive trees with Dp (\%) } & \multicolumn{6}{|c|}{ Positive trees with Ds $(\%)^{d}$} \\
\hline & & \multicolumn{3}{|c|}{ Bark } & \multicolumn{3}{|c|}{ Wood } & \multicolumn{3}{|c|}{ Bark } & \multicolumn{3}{|c|}{ Wood } & \multicolumn{3}{|c|}{ Bark } & \multicolumn{3}{|c|}{ Wood } \\
\hline & & Mean & Range & SE & Mean & Range & SE & Mean & Range & SE & Mean & Range & SE & Mean & Range & SE & Mean & Range & SE \\
\hline Adams & Red & 90 & $70-100$ & 10 & 83 & $70-90$ & 7 & 92 & $86-100$ & 4 & 89 & $78-100$ & 6 & 15 & $0-30$ & 9 & 11 & $0-22$ & 6 \\
\hline Co. & Jack & 83 & $60-100$ & 12 & 93 & $80-100$ & 7 & 52 & $50-56$ & 2 & 61 & $50-70$ & 6 & 62 & $50-70$ & 6 & 43 & $30-60$ & 9 \\
\hline BRSF & Red & 100 & 100 & 0 & 80 & $70-90$ & 6 & 60 & $30-100$ & 20 & 69 & $50-100$ & 15 & 40 & $0-70$ & 21 & 36 & $0-63$ & 19 \\
\hline & Jack & 83 & $70-100$ & 9 & 67 & $30-90$ & 19 & 26 & $10-43$ & 9 & 12 & $0-25$ & 7 & 87 & $71-100$ & 8 & 88 & $75-100$ & 7 \\
\hline
\end{tabular}

${ }^{\text {a }}$ Recently killed seedlings and saplings that had developed naturally from seed were sampled at three sites (replicates) in each of the two locations. One dead seedling of each species was sampled in each of 10 plots located at intervals of at least $10 \mathrm{~m}$ along a transect across each site ( 30 trees of each species per location).

b Analysis of variance of transformed data did not indicate effects of location, pine species, tissue (bark or wood), or interactions on percentages of dead trees that tested positive for either pathogen (values of $P>0.17$ ).

c Analysis of variance of transformed data indicated effects of location $(P<0.01)$ and pine species $(P<0.01)$, but not tissue or interaction $($ values of $P>0.36)$ on percentages of positive dead trees with $D$. pinea.

d Analysis of variance of transformed data indicated effects of location $(P=0.01)$ and pine species $(P<0.01)$, but not tissue or interaction $($ values of $P>0.46)$ on percentages of positive dead trees with $D$. scrobiculata 
of dead seedlings or saplings that tested positive for either pathogen $(P>0.17$ in all cases).

Results differed, however, for frequency of detection of $D$. pinea among positive trees (Table 3). Both bark and wood of dead red and jack pine seedlings or saplings from Adams Co. tested positive for $D$. pinea more frequently than bark and wood of the respective species from BRSF ( $P<0.01$ for effect of location). Also, both bark and wood of dead red pines from each location tested positive for $D$. pinea more frequently than bark and wood from dead jack pines from the respective locations ( $P$ $<0.01$ for effect of pine species). Analysis of variance did not indicate effects of tissue (bark or wood) or interactions on frequencies of positive dead trees with $D$. pinea ( $P>0.36$ in all cases).

Results also varied for frequency of detection of $D$. scrobiculata among positive trees (Table 3). Both bark and wood of dead red and jack pine seedlings or saplings from BRSF tested positive for $D$. scrobiculata more frequently than bark and wood of the respective species from Adams Co. $(P=0.01$ for effect of location). Also, both bark and wood of dead jack pines from each location tested positive for D. scrobiculata more frequently than bark and wood from dead red pines from the respective locations $(P<0.01$ for effect of pine species). Analysis of variance did not indicate effects of tissue (bark or wood) or interactions on frequencies of positive dead trees with $D$. scrobiculata $(P>0.46$ in all cases).

Individual bark and wood samples from a dead tree usually were positive for only one pathogen and usually the bark and wood samples contained the same pathogen. However, of the 60 samples of bark and 60 samples of wood from dead trees of each host, two red pine bark samples, seven jack pine bark samples, one red pine wood sample, and one jack pine wood sample tested positive for both pathogens. Bark samples were positive (for at least one pathogen) and respective underlying wood samples were negative for 11 dead red pines and 10 dead jack pines. Bark samples were negative and respective underlying wood samples were positive (for at least one pathogen) for two dead red pines and eight dead jack pines.

Test results for samples from live trees rarely were positive. Of the samples collected from the live trees at both locations, three of 39 red pine bark samples and none of 43 jack pine bark samples were positive for D. pinea. Also, one of 39 red pine bark samples and three of 43 jack pine bark samples were positive for D. scrobiculata. None of the 39 red pine wood samples and none of the 43 jack pine wood samples from live trees at the two locations were positive for either pathogen. Water controls included with PCR reactions never were positive for either pathogen.

\section{DISCUSSION}

The ability to directly test host tissues to unambiguously confirm the species of pathogen that is present is an improvement over previous PCR assays for identification of D. pinea and D. scrobiculata. Although species-specific RAPD markers and ISSR fingerprint markers had been identified previously, these have been used after pure cultures of pathogens have been obtained $(7,33,40)$. As mentioned previously, Flowers et al. (10) developed a nested PCR assay using nuclear rDNA ITS primers that should detect $D$. pinea, $D$. scrobiculata, and B. obtusa in pine tissues, but results of that assay do not differentiate among these three species. These pathogens have wide geographic distributions and broad, overlapping host ranges $(21,22)$. For example, routine conifer disease surveys in Ontario yielded not only $D$. pinea and D. scrobiculata, but also isolates from jack pine, red pine, and white spruce (Picea glauca) that ultimately were identified as $B$. obtusa $(7,13)$. Therefore, our new primers should be particularly useful during further studies in areas where $D$. pinea, D. scrobiculata, and B. obtusa or other closely related fungi could all be present.

Specificity of the new primer pairs can be attributed to the substantial variation in the 19-bp region of mt SSU rDNA that the forward primers span. We examined this region of the genome because, although nuclear rDNA ITS sequences have been used to design primers for identification of many species of fungi, as well as prokaryotes, plants, and animals, sequences in the ITS region vary little for some Botryosphaeria species and related anamorphic fungi (42). The ITS sequences for $D$. pinea and $D$. scrobiculata differ by only two nucleotides, and differ from the sequence of their close relative $B$. obtusa by only two other nucleotides. In theory, these minor differences could be sufficient to allow design of useful specific primers. However, due to the location of these particular nucleotides, primers cannot be designed to permit differential PCR reactions. Similarly, Luchi et al. (16) found no differences in a partial sequence of nuclear SSU rRNA of $D$. pinea and D. scrobiculata. They did, however, develop a nonspecific primer pair to allow real-time quantitative PCR assay of $D$. pinea in pine shoots inoculated with only this pathogen.

The method by which DNA is extracted from the plant tissues may affect the results of the PCR-based assays. Although it is more labor intensive and timeconsuming, the extraction method of Cubero et al. (8) produced fewer negative results from red pine needles and red pine bark containing $D$. pinea pycnidia and spores than simpler DNA extraction methods. Even though others have used the standard CTAB plant DNA extraction procedure on Austrian pine tissues success- fully (10), simpler extraction procedures may fail to remove or inactivate some chemicals present in red pine tissues that could interfere with PCR or damage DNA. The ability to detect 50 to 100 times less fungal DNA when dissolved in water rather than red or jack pine DNA extract indicates that some interference with the PCR is still occurring even when using Cubero's DNA extraction method.

Because fungal hyphae can contain numerous mitochondria (50 to 90 copies of the mitochondrial genome per cell for yeast [12]), mt SSU rDNA should exist in a high enough copy number to have a detection limit similar to nuclear rDNA ITS. For some tissues, however, our assay was not as sensitive as the assay of Flowers et al. (10). Their nested PCR assay using ITS primers allowed detection of five to ten times less DNA in bark than our assay. Again, possible differences in quantity or quality of interfering compounds in bark of Austrian pine (assayed by Flowers et al. [10]) as compared to red pine and jack pine could explain this difference. However, greater sensitivity might result from the nested nature of their assay, in which universal ITS primers are used first, followed by the primers for more specific DNA amplification. In our own assay, greater sensitivity in wood extract as compared to bark or needle extracts is probably due to interfering compounds in the latter. Despite greater sensitivity in wood extracts, however, our assay occasionally failed to detect either pathogen in wood underlying a positive bark sample. Although in these cases neither pathogen may have been present in the wood, this result also might have occurred due to difficulty in always completely grinding wood samples.

In contrast to the negative results for some symptomatic tissues, a small number of samples from healthy trees were positive for one or the other pathogen. Because these positive results were always from bark, they could be explained by the presence of spores on the surface of the stem. An alternative explanation is that we detected latent infections, a common occurrence in the basal stem area of nursery red and jack pine seedlings and branches of forest trees $(28,31)$.

Similar mean frequencies of detection of the respective pathogens from both bark and wood suggest that only one tissue would need to be collected and tested using these methods in future surveys. For example, field sampling could be limited to symptomatic bark, or these pathogens could be detected from materials lacking bark (such as stained lumber). Unfortunately, the small size of the sample that can be easily ground and extracted could limit the usefulness of this detection method. Cultural assay methods using stem segments $(2,28,31)$ have the potential to detect the pathogen's presence any- 
where in or on a much greater volume of host material, potentially increasing efficiency compared to the very small bit of tissue used for the PCR-based assay. Conversely, the ability to detect these fungi in very small amounts of host material may allow dissection of samples into very small pieces to investigate relative abundance and distribution of these pathogens within different host tissues and organs.

In contrast to current knowledge of the broad-scale geographic distribution of $D$. pinea and D. scrobiculata, relatively little is known about their local co-occurrence. Reports of Palmer et al. (20) and Palmer (18) include recognition of both species in the same county or even the same red pine plantation in Michigan, Minnesota, and Wisconsin. Similarly, we detected both $D$. pinea and D. scrobiculata at all six sampled sites. Our results and earlier reports also confirm the potential for intimate association between $D$. pinea and $D$. scrobiculata within host tissues. Consistent with our detection of both species from some individual samples, Morelet and Chandelier (17) isolated both $D$. pinea and D. scrobiculata from the collar of a declining Cedrus deodara tree. Attempts by Palmer et al. (20) to reisolate D. pinea from jack pines artificially inoculated with that species also yielded isolates of $D$. scrobiculata. The implications of cooccurrence of these pathogens in the same forests, trees, and tissues for the production of inoculum, disease development, and subsequent survival are possible subjects for future study.

The location effect indicated by our data also demonstrates the potential for one species to be more prevalent, or at least detected more frequently, than the other species within the geographic range in which they both occur. This tendency also was indicated by results of Palmer (18). During that investigation of isolate types associated with top kill of red pines in Minnesota and Wisconsin, plantations tended to yield only one, or predominantly one, of these two fungi. For example, although both species were present, $D$. pinea was much more common among isolates from a Hubbard Co., MN red pine plantation, and D. scrobiculata was much more common among isolates from a Wadena Co., MN red pine plantation. Although results from inoculation trials in both greenhouse and field experiments indicate that $D$. pinea can be more aggressive than D. scrobiculata (1,3-6), differences in capacity for sporulation, survival, or responses of these two species to host and environmental conditions that could also affect prevalence in a particular location or region are not known.

The particular pathogen species (i.e., $D$. pinea or D. scrobiculata) associated with collar rot symptoms observed in field situations have not been determined previously. Although collar rot has been noted infrequently on small numbers of red pine seedlings in the nursery by Palmer and Nicholls (19) and commonly on large numbers of planted red pine seedlings and saplings by Stanosz and Cummings Carlson (26), identification of the associated fungus (or fungi) as Sphaeropsis sapinea sensu lato was made only on the basis of the gross morphology of conidia. Identification of both $D$. pinea and $D$. scrobiculata on trees sampled in this study suggests the possibility that each of these species could play a role in collar rot development and subsequent mortality. This potential has been proven for $D$. pinea, identified by Stanosz et al. (25) (on the basis of analysis of RAPD markers) as the pathogen that was detected from asymptomatic red pine nursery seedlings and proliferated to cause collar rot and kill these seedling when subjected to drought stress in greenhouse experiments. In contrast, whether or not $D$. scrobiculata is actually capable of causing collar rot and killing trees is unknown. However, D. scrobiculata recently was identified among isolates obtained from surface-disinfested lower stem segments of asymptomatic red pine nursery seedlings in Minnesota (28). In addition, Blodgett and Bonello (1) recently confirmed the ability of an isolate of $D$. scrobiculata to colonize the lower stems of wounded and then inoculated Austrian pines in a greenhouse trial. Further studies are necessary to prove the potential of $D$. scrobiculata as an aggressive pathogen capable of causing the mortality with which it was associated in our current survey.

The previous association of Sphaeropsis sapinea sensu lato with collar rot symptoms occurring in the field also was limited to occurrence on planted red pine seedlings and saplings (26). Detection of $D$. pinea and D. scrobiculata in our study has proven that naturally occurring seedlings of both pine species can acquire the fungus from natural inoculum sources. The potential for these pathogens to persist in forests and interfere with natural regeneration of these native species may present a great challenge to managers attempting to maintain these ecologically and economically important species in forests of the Great Lakes region.

\section{ACKNOWLEDGMENTS}

The authors gratefully acknowledge our USDA Forest Service cooperator Joe O'Brien, the Wisconsin Department of Natural Resources (especially Jack Halbrehder, Black River State Forest), Plum Creek Timber Company (especially Joel Aanensen), Isabel Munck for assistance with sample collection, Patricia McManus for presubmission review, and persons who provided specimens or isolates. Partial funding was provided by the USDA (Hatch), the USDA Forest Service Forest Health Monitoring Program, and the USDA Forest Service Special Technology Development Program.

\section{LITERATURE CITED}

1. Blodgett, J. T., and Bonello, P. 2003. The aggressiveness of Sphaeropsis sapinea on Austrian pine varies with isolate group and site of infection. For. Pathol. 33:15-19.

2. Blodgett, J. T., Bonello, P., and Stanosz, G. R. 2003. An effective medium for isolating Sphaeropsis sapinea from asymptomatic pines. For. Pathol. 33:395-404.

3. Blodgett, J. T., Kruger, E. L., and Stanosz, G. R. 1997. Effects of moderate water stress on disease development by Sphaeropsis sapinea on red pine. Phytopathology 87:422-428.

4. Blodgett, J. T., Kruger, E. L., and Stanosz, G. R. 1997. Sphaeropsis sapinea and water stress in a red pine plantation in central Wisconsin. Phytopathology 87:429-434.

5. Blodgett, J. T., and Stanosz, G. R. 1997. Sphaeropsis sapinea morphotypes differ in aggressiveness, but both infect nonwounded red or jack pines. Plant Dis. 81:143-147.

6. Blodgett, J. T., and Stanosz, G. R. 1999. Differences in aggressiveness of Sphaeropsis sapinea RAPD marker group isolates on several conifers. Plant Dis. 83:853-856.

7. Burgess, T., Wingfield, M. J., and Wingfield, B. W. 2001. Simple sequence repeat markers distinguish among morphotypes of Sphaeropsis sapinea. Appl. Environ. Microbiol. 67:354 362.

8. Cubero, O. F., Crespo, A., Fatehi, J., and Bridge, P. D. 1999. DNA extraction and PCR amplification method suitable for fresh, herbarium-stored, lichenized, and other fungi. Plant Syst. Evol. 216:243-249.

9. de Wet, J., Burgess, T., Slippers, B., Preisig, O., Wingfield, B. D., and Wingfield, M. J. 2003. Multiple gene genealogies and microsatellite markers reflect relationships between morphotypes of Sphaeropsis sapinea and distinguish a new species of Diplodia. Mycol. Res. 107:557-566.

10. Flowers, J., Hartman, J., and Vaillancourt, L. 2003. Detection of latent Sphaeropsis sapinea infections in Austrian pine tissues using nested-polymerase chain reaction. Phytopathology 93:1471-1477.

11. Flowers, J., Nuckles, E., Hartman, J., and Vaillancourt, L. 2001. Latent infection of Austrian and Scots pine tissues by Sphaeropsis sapinea. Plant Dis. 85:1107-1112.

12. Grimes, G. W., Mahler, H. R., and Perlman, P. S. 1974. Nuclear gene dosage effects on mitochondrial mass and DNA. J. Cell Biol. 61:565574.

13. Hausner, G., Hopkin, A. A., Davis, C. N., and Reid, J. 1999. Variation in culture and rDNA among isolates of Sphaeropsis sapinea from Ontario and Manitoba. Can. J. Plant Pathol. 21:256-264.

14. Heinze, B. 1994. RAPD reactions from crude plant DNA. Mol. Biotechnol. 1:307-310.

15. Li, K. N., Rouse, D. I., and German, T. L. 1994. PCR primers that allow intergenic differentiation of ascomycetes and their application to Verticillium spp. Appl. Environ. Microbiol. 60:4324-4331.

16. Luchi, N., Capretti, P., Surico, G., Orlando, C., Pazzagli, M., and Pinzani, P. 2005. A real-time quantitative PCR assay for the detection of Sphaeropsis sapinea from inoculated Pinus nigra shoots. J. Phytopathol. 153:37-42.

17. Morelet, P. M., and Chandelier, P. 1993. Sur un cas de variabilité chez Sphaeropsis sapinea. Eur. J. For. Pathol. 23:317-320.

18. Palmer, M. A. 1991. Isolate types of Sphaeropsis sapinea associated with main stem cankers and top-kill of Pinus resinosa in Minnesota and Wisconsin. Plant Dis. 75:507-510.

19. Palmer, M. A., and Nicholls, T. H. 1985. Shoot blight and collar rot of Pinus resinosa caused by Sphaeropsis sapinea in forest tree nurseries. Plant Dis. 69:739-740.

20. Palmer, M. A., Stewart, E. L., and Wingfield, M. J. 1987. Variation among isolates of Sphaeropsis sapinea in the north central United States. Phytopathology 77:944-948.

21. Punithalingam, E., and Waller, J. M. 1973. 
Botryosphaeria obtusa. Commonwealth Mycol. Inst. Descr. Pathogenic Fungi and Bacteria 394.

22. Punithalingam, E., and Waterston, J. M. 1970. Diplodia pinea. Commonwealth Mycol. Inst. Descr. Pathogenic Fungi and Bacteria 273.

23. Smith, D. R., and Stanosz, G. R. 1995. Confirmation of two distinct populations of Sphaeropsis sapinea in the north central United States using RAPDs. Phytopathology 85:699-704.

24. Solel, Z., Madar, Z., Kimchi, M., and Golan, Y. 1987. Diplodia canker of cypress. Can. J. Plant Pathol. 9:115-118.

25. Stanosz, G. R., Blodgett, J. T., Smith, D. R., and Kruger, E. L. 2001. Water stress and Sphaeropsis sapinea as a latent pathogen of red pine seedlings. New Phytol. 149:531-538.

26. Stanosz, G. R., and Cummings Carlson, J. 1996. Association of mortality of recently planted seedlings and established saplings in red pine plantations with Sphaeropsis collar rot. Plant Dis. 80:750-753.

27. Stanosz, G. R., and Kimbler, D. L. 1997. Shoot blight of lodgepole pine seedlings in Nebraska caused by Sphaeropsis sapinea. Plant Dis. $81: 311$

28. Stanosz, G. R., Smith, D. R., and Albers, J. S. 2005. Surveys for asymptomatic persistence of Sphaeropsis sapinea on or in stems of red pine seedlings from seven Great Lakes region nurseries. For. Pathol. 35:233-244.

29. Stanosz, G. R., Smith, D. R., and Guthmiller,
M. A. 1996. Characterization of Sphaeropsis sapinea from the west central United States by means of random amplified polymorphic DNA marker analysis. Plant Dis. 80:1175-1178.

30. Stanosz, G. R., Smith, D. R., and Guthmiller, M. A. 1997. Pathogenicity of A and B morphotypes of Sphaeropsis sapinea confirmed on American larch (tamarack) and European larch. Eur. J. For. Pathol. 27:301-307.

31. Stanosz, G. R., Smith, D. R., Guthmiller, M. A., and Stanosz, J. C. 1997. Persistence of Sphaeropsis sapinea on or in asymptomatic shoots of red and jack pines. Mycologia 89:525-530.

32. Stanosz, G. R., Swart, W. J., and Smith, D. R 1998. Similarity between fungi identified as Diplodia pinea f. sp. cupressi in Israel and Botryosphaeria stevensii or Diplodia mutila on Juniperus in the United States. Eur. J. For Pathol. 28:33-42.

33. Stanosz, G. R., Swart, W. J., and Smith, D. R. 1999. RAPD marker and isozyme characterization of Sphaeropsis sapinea from diverse coniferous hosts and locations. Mycol. Res. 103:1193-1202

34. Swart, W. J., Wingfield, M. J., Palmer, M. A., and Blanchette, R. A. 1991. Variation among South African isolates of Sphaeropsis sapinea. Phytopathology 81:489-493.

35. Swart, W. J., Wingfield, M. J., and Van Wyk, P. 1993. Variation in conidial morphology among geographic isolates of Sphaeropsis sapinea. Mycol. Res. 97:832-838.
36. Thompson, J. D., Gibson, T. J., Plewniak, F., Jeanmougin, F., and Higgins, D. G. 1997. The ClustalX windows interface: Flexible strategies for multiple sequence alignment aided by quality analysis tools. Nucleic Acid Res. 25:4876-4882.

37. Wang, C.-G., and Blanchette, R. A. 1986. Ultrastructural aspects of the conidium cel wall of Sphaeropsis sapinea. Mycologia 78:960-963.

38. Wang, C.-G., Blanchette, R. A., Jackson, W. A., and Palmer, M. A. 1985. Differences in conidial morphology among isolates of Sphaeropsis sapinea. Plant Dis. 69:838-841.

39. Wingfield, M. J., and Knox-Davies, P. S. 1980. Association of Diplodia pinea with a root disease of pines in South Africa. Plant Dis. 64:221-223.

40. Zhou, S., Smith, D. R., and Stanosz, G. R. 2001. Differentiation of Botryosphaeria species and related anamorphic fungi using inter simple or short sequence repeat (ISSR) fingerprinting. Mycol. Res. 105:919-926.

41. Zhou, S., and Stanosz, G. R. 2001. Primers for amplification of mt SSU rDNA, and a phylogenetic study of Botryosphaeria and associated anamorphic fungi. Mycol. Res. 105:1033 1044.

42. Zhou, S., and Stanosz, G. R. 2001. Relationships among Botryosphaeria species and associated anamorphic fungi inferred from the analyses of ITS and 5.8S rDNA sequences. Mycologia 93:516-527. 